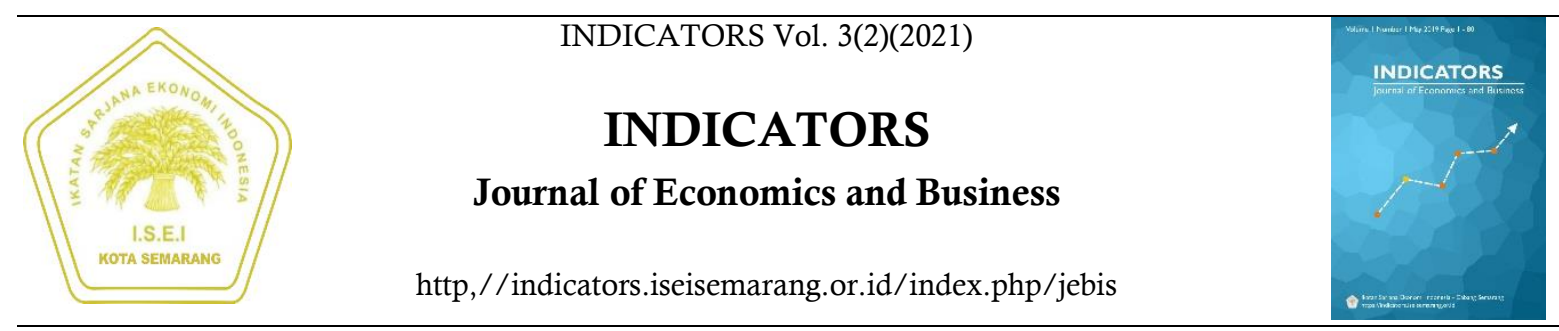

\title{
THE EFFECTIVENESS OF VILLAGE FUND MANAGEMENT ON COMMUNITY WELFARE IN KEDUNGRINGIN VILLAGE, SURUH DISTRICT, SEMARANG DISTRICT 2016-2019
}

\author{
Yunita Rhoman Maulany ${ }^{1 凶}$, Fafurida ${ }^{2}$ \\ ${ }^{1,2}$ Fakultas Ekonomi, Universitas Negeri Semarang, Indonesia
}

\begin{tabular}{ll}
\hline Article & Abstract \\
Information & $\begin{array}{l}\text { The village is a residential area where most of the population makes a living in agriculture. Most of Indonesia's } \\
\text { population are residents who live in rural areas. The village government can use village funds as a source of } \\
\text { financing for village household needs in order to improve the welfare of the village community. This study aims } \\
\text { to analyze the effectiveness of village fund management on the welfare of village communities in Kedungringin } \\
\text { History of Article, }\end{array}$ \\
$\begin{array}{l}\text { Received August } 2021 \\
\text { Accepted September } 2021\end{array}$ \\
$\begin{array}{l}\text { Published November Suruh District, Semarang Regency. Data collection methods used are through observation and literature } \\
\text { study, then analyzed using descriptive qualitative data analysis methods. The results of the study were the } \\
\text { management of village funds based on indicators of goal achievement, timeliness, benefits, and results in } \\
\text { accordance with community expectations. As well as village funds also play a role in developing the economy of } \\
\text { the village community so that it can improve the welfare of the village community through the existence of } \\
\text { development and community empowerment programs. }\end{array}$ \\
$\begin{array}{l}\text { Keywords, } \\
\text { effectiveness, village funds, } \\
\text { management, community }\end{array}$
\end{tabular}

management, community

welfare, Semarang Regency

\footnotetext{
Correspondence:

J1. Kampus Timur, Sekaran, Gunung Pati, Semarang City, Central

Java 50229

Email: yunitarhoman@outlook.com
}

\section{INTRODUCTION}

The village is a residential area where most of the population makes a living in agriculture. Most of Indonesia's population are residents who live in rural areas. Village government is a government unit under the subdistrict and has the right to autonomy to manage its own household affairs. According to Widjaja (2003) village autonomy is genuine, unanimous and complete autonomy and is not a gift from the government. So that the village can run its household in accordance with the autonomy that has been given, the village must carry out management and financing related to village development for the welfare of the community.

According to Riyani (2016), the main purpose of implementing autonomy is to improve public services and improve the regional economy. One of the forms of autonomous villages that with the funds the village. Dana village is a thing that is important for the village to support the process of implementation of development in each village as a source of financing-financing program villages . Village funds are funds sourced from 
the State Revenue and Expenditure Budget (APBN) allocated to villages that are transferred through the district / city Regional Income and Expenditure Budget (APBD) and are used to finance governance, implementation of development, community development, and community empowerment. The existence of village funds is expected to improve the welfare and equitable distribution of village development through improving infrastructure and improving public services in the village and advancing the village economy.

The village government can use village funds as a source of financing for village household needs in order to improve the welfare of the village community. The amount of village funds or the village fund ceiling received by each village varies from one village to another according to several predetermined provisions. Village funds have been provided since 2015, the purpose of providing village funds is to finance village development programs and village community empowerment programs to improve the welfare of village communities.

Villages have broader authority in development planning and financial management aimed at improving welfare. Development in the village is a participatory development model, namely a joint development management system that is planned, implemented and evaluated by means of deliberation, consensus and mutual cooperation which is a way of life for people that has long been rooted in the Indonesian regional culture (Saputra, 2016)

Although many parties acknowledge that the village has a big role for an area, it is still considered inferior in economic terms or in other matters. Therefore, it is only natural that rural development should be a top priority in all strategic plans and development policies in Indonesia (Hernowo, 2004) .

Village development aims to increase village productivity, improve the quality of life of rural communities, and also reduce poverty in rural areas. In other words, village development means efforts to improve the welfare of rural communities. To carry out village development, the village needs a budget. One of the budgets to finance village needs is the village fund budget. Village funds are expected to be able to improve community welfare.

Semarang Regency consists of 19 subdistricts, each of which has a different number of pre-prosperous families. Suruh Subdistrict is a sub-district with the highest number of preprosperous or poorly-prosperous households compared to other sub-districts, with the lowest number of prosperous households of 7,023 families. Meanwhile, the highest number of poor families from year to year is in Suruh Subdistrict, namely Kedungringin Village. In this study the authors took a case study in Kedungringin Village, Suruh District, Semarang Regency. Kedungringin Village is the village with the lowest level of welfare compared to other villages in the sub-district of Suruh based on the number of pre-prosperous families. This study the authors will analyze the effectiveness of village fund management on the welfare of the people of Kedungringin Village.

\section{RESEARCH METHOD}

Type of research in the study of this is descriptive quantitative. Design research desktiptif is a design study of the most basic. Research descriptive shown to describe or illustrate the phenomena that exist. both phenomena are natural and which are engineered humans. The study is assessing the form of activity, characteristics, changes, relationships, similarities, and differences with phenomena other ( Sukmadinata, 2009). While the study of quantitative composed on the formulation of the problem, construct a model, get the data, searching for solutions, analyze the results, and implement results ( Kuncoro, 2007).

In this study, there are two types of data used, namely secondary data. Secondary data is data obtained through reports / books / notes that are closely related to the problems studied, secondary data in this study were obtained from the Central Bureau of Statistics (BPS) Semarang Regency in the form of population data and the number of pre-prosperous families. also data obtained from the Kedungringin Village Government in the form of a village fund ceiling, realization of village funds, and 
several other supporting data. Research variables are factors that play a role in the events and symptoms to be studied or often referred to as research objects (Cholid Narbuko and Abu Achmadi, 2013). Meanwhile, according to Kuncoro (2007), a variable is a measurable amount that can vary or change easily. Variable this study include, (1) The achievement of objectives is conformity between the use of village funds so that the purpose of funding the priority needs of the village can be reached. (2) Punctuality that the process of distribution and use of village funds in accordance with the timing of the planned activities until the end of the activity or program that is funded by the village. (3) Benefits which funds the village can benefit the village as beneficiaries of the program. (4) Results, results, namely village programs financed by village funds, the results are in accordance with community expectations.

The data collection method is very important because it is a tool for obtaining data in accordance with the desired objectives. Data collection methods used in this research are documentation and literature study. Literature study is done by collecting literature related to the object of study. Meanwhile, the documentation method is to find data about things or variables in the form of notes, transcripts, books, newspapers, magazines, inscriptions, meeting minutes, notes, agendas, and so on (Arikunto, 2006).

The data analysis method is used to process the data obtained during the research. In this study using a qualitative descriptive research method. According to Dethan (2019), to measure the effectiveness of the use of village funds, there are several aspects that need to be considered, which include, goal achievement, timeliness, benefits, and results in accordance with community expectations.

\section{RESULT AND DISCUSSION}

Kedungringin Village, Suruh Subdistrict, Semarang Regency is located on the border of Semarang Regency and Boyolali Regency, about $9 \mathrm{~km}$ from the Suruh District office. Kedungringin Village, Suruh Subdistrict, Semarang Regency, has a total area of 485 ha, administratively consisting of 8 hamlets, $8 \mathrm{RW}$ and 51 RT. Village funds received by Kedungringin Village have always increased from year to year as shown in the graph above. In 2016 the village funds received were IDR $694,614,000$ then in 2017 the village funds received were IDR 855,649,000, while in 2017 the village funds received were IDR $978,582,000$, and in 2019 the village funds received received in the amount of IDR $1,408,352,000$.

Based on indicators of goal achievement, village funds for the use of village funds for 2016-2019 are used quite effectively. The village funds used are in accordance with the priority for the use of village funds each year. In 2016, village funds were used according to the priority for the use of village funds. However, in 2017 village funds should be prioritized for community development and empowerment programs, and in fact they are only used for village development programs. Furthermore, in 2018, village funds are used according to predetermined priorities. And in 2019, village funds are used according to predetermined priorities coupled with the use of village funds for other programs such as government administration and community development.

The use of village funds for 2016-2019 is based on indicators of timeliness, the village fund program is implemented effectively. From 2016 to 2019 the village fund program was implemented properly as targeted. Because the implementation of the village fund program is carried out according to a predetermined time and ends before or in accordance with the target time for the end of the activity program.

Based on the benefit indicators, the use of village funds from 2016 to 2019 has been effective because almost all village fund programs that have been implemented can benefit the entire community. Programs that can be directly implemented benefit such as road construction, bridge construction and clean water supply. The implementation of village fund programs or activities is prioritized in a self-managed manner using local resources / raw materials, and is pursued by absorbing more labor from the village community. Village funds can be used to finance activities that are not included in the priority use of village funds if the priorities or development and community 
empowerment programs have been met. The following is an evaluation of the use of village funds and their benefits for the welfare of the people of Kedungringin Village.

In the field of government administration, village funds are used for the preparation of planning documents. However, this program does not directly affect the welfare of the community. Meanwhile, in the field of village physical development, road construction, bridges and road gutters are carried out. This development was carried out to facilitate access of rural communities in carrying out economic activities. With the repair of roads and bridges and road gutters, the distance to other villages will be shorter and the village community becomes easier to carry out mobility for their daily needs. Planning is one of the important elements in village development because it is to prepare village development to run smoother and in accordance with community expectations. With the existence of a village planning program or activity, the government, the village government can carry out directed village development so that the implementation of village programs can be carried out properly.

The field of government administration is not included in the priority for the use of village funds, however, the village government can use village funds for programs or activities from the field of government administration as long as priorities for development and community empowerment have also been implemented. The benefits of government document planning programs cannot be felt directly by the community, but with the preparation of village plans, the programs to be implemented can be implemented properly and with direction. The programs arranged in the plan aim to improve the welfare of the people of Kedungringin village.

In the development sector, most of it is used for public works and spatial planning subprograms in the form of village infrastructure development, such as road construction, bridges and talud. Village funds are prioritized for village development and community empowerment to improve the welfare of village communities. Kedungringin Village has implemented many village development programs, both from the public works and spatial planning sub-sector, the education subsector, and the health sub-sector. Programs that have been implemented such as the infrastructure development program are felt to have facilitated various economic activities of rural communities.

Village funds are considered capable of meeting basic general needs for the community in terms of village development. The implementation of village fund programs is carried out in mutual cooperation and the community also participates in the program proposal so that the results get the desired and needed by the community. The existence of village development programs can help solve community problems, especially problems with road infrastructure, bridges, gutters, culverts and the provision of clean water.

Village funds are used to finance village development based on program urgency and development priorities considering the number of programs proposed and to be completed compared to the amount of village funds available. From year to year, the village funds received by Kedungringin Village have increased which can be used to increase village development so that the infrastructure in the village continues to experience improvement and can facilitate various economic activities of the village community.

Road construction can improve welfare, especially for rural people who work as good traders who sell it from house to house (mobile vegetable traders, mobile siomay traders, other food traders, etc.). So that economic activities in Kedungringin Village are more active. Village funds are also used for the provision of clean water, so that the water needs of the village community can be met.

In the field of community development, village funds are used for programs in the education sub-sector, the youth and sports subsector, and the investment support sub-sector. Programs in the sub-sector of education are used to pay for honoraria for TPA administrators and teachers. In the field of youth and sports, village funds are used for organizing youth festivals / competitions and sports programs. Activities carried out are festivals / sports competitions at the village 
level. These activities are carried out to commemorate independence day.

In the sub-sector, investment support is used for training in community institution development. The activity of coaching community institutions is a coaching effort from the village government to improve the performance of the institutions under it so that they can work well and assist the government in advancing the village. These institutions include RT, RW, Karang Taruna, PKK, security, and others. Of these programs, there are programs that can be directly felt by the village community and some that cannot be directly felt by the village community. in the sub-sector of village fund education.

In the field of community empowerment, adesa is used for training courses for village apparatus and for investment support in the form of BUMdes formation. The village apparatus training course program has no direct effect on the welfare of the village community. Meanwhile, the BUMdes formation program will have a direct impact on the welfare of the village community because the existence of BUMdes can boost the economic productivity of the community.

Community empowerment is one of the priorities for the use of village funds in addition to village development to improve the welfare of village communities. Village funds are used for financing in the sub-sector of increasing the capacity of the village apatur in the form of training courses for village officials and in the sub-sector of investment support in the form of BUMDes formation. Kedungringin Village began using village funds for the field of community empowerment in 2019 , in previous years village funds were used for village development.

In the sub-sector of increasing the capacity of the village apatur, village funds are used to finance training courses for village apparatus. With the increasing capacity of village government officials, there will be positive implications for the resulting activities and substances. The availability of adequate information and knowledge aims to develop his abilities because this is necessary to carry out his work, especially in village development. The benefits of this program cannot be felt directly by the village community, but with the village apparatus capacity building program, village officials are expected to be able to take action if there are problems in planning and implementing village development.

\section{CONCLUSION}

The effectiveness of the management of funds village in rural Kedungringin years 20162019 from the terms of the achievement of objectives is quite effective because the funds the village used in accordance with the priority needs of the village, while on the terms of the accuracy of the time has been effective because the process of disbursement of funds the village in accordance with the time that the implementation of the program which has been planned until the end of program. from the terms of the benefit or the suitability of the benefits, the management of the funds the village has been effective because the results of the program funds the village can be perceived benefit by the public, as well as from the terms of the results in accordance with the expectations of society, the management of the funds the village has been managed with effective because the programs are implemented Sesua i with proposals from community. The management of village funds is beneficial for the welfare of village communities, especially in the field of village physical development and community empowerment because with the construction of village infrastructure, economic activities in the village can develop even more. It is hoped that the Kedungringin Village Government can add to programs in the field of community empowerment such as holding training and coaching for farmers because the majority of the villagers live as farmers.

\section{REFERENCES}

Bintarto, R. (1983). Interaksi Desa-Kota dan Permasalahannya. Ghalia Indonesia.

Duncan, J. W. (1985). Organization Behaviour. Houghton Mifflin

Halim, A. (2002). Akuntansi Keuangan Daerah. Jakarta: Salemba Empat

Handayaningrat, S. (1994). Pengantar Studi Ilmu Administrasi dan Manajemen. Jakarta: Haji Masagung 
Hernowo, B. (2004). Kajian pembangunan ekonomi desa untuk mengatasi kemiskinan. Artikel Jurnal, 1(1).

Indonesia, P. R. (2014). Peraturan Pemerintah Nomor 60 Tahun 2014 tentang Dana Desa yang Bersumber Dari APBN. 118.

Narbuko, C. \& Achmadi, A. (2013). Metodologi Penelitian. Jakarta: Bumi Aksara.

Ndraha, T. (1997). Budaya Organisasi. Jakarta: Rineka Cipta

Riyani, N., \& Sumardjoko, B. (2016). Analisis Pengelolaan Dana Desa (Studi Kasus di Desa Singopuran Kecamatan Kartasura Kabupaten Sukoharjo Tahun 2016) (Doctoral dissertation, Universitas Muhammadiyah Surakarta).

Sukmadinata, N. S. (2009). Metode Penelitian Pendidikan. Bandung: PT Remaja Rosdakarya.

Undang- Undang Republik Indonesia No 6 Tahun 2014 Tentang Desa

Widjaja, H.A.W. (2003). Otonomi Daerah. Jakarta: Raja Grafindo Persada 